\title{
Can the implementation of Low Impact Development reduce basin runoff?
}

\author{
Xinxin Sui ${ }^{1,2}$, Frans van de Ven ${ }^{2,3}$ \\ ${ }^{1}$ Water Resources Section, Faculty of Civil Engineering and Geosciences, Delft University of Technology, 2628 \\ 5 CD Delft, the Netherlands \\ ${ }^{2}$ Department of Civil and Environmental Engineering, National University of Singapore, 117576 Singapore, \\ Singapore \\ ${ }^{3}$ Deltares, 2629 HV Delft, the Netherlands \\ Correspondence to: Frans van de Ven (F.H.M.vandeVen@tudelft.nl); Xinxin Sui (SuiXinxin95@163.com)
}

10 Abstract. Low impact development (LID) was promoted as an alternative to conventional urban drainage methods. The effects of LID at site or urban scales have been widely evaluated. This project aims to investigate the impact of LID implementation on basin runoff at regional scale in a half urbanized catchment; especially the overlap of urban and rural sub-flows at peak times is concerned. A SUPERFLEX conceptual model framework was adapted as a semi-distributed model to simulate the rainfall-runoff relationship in the catchment for San

15 Antonio, Texas as a case study. Scenario analyses of both urban development and LID implementation were conducted. Results show that (1) the infill urban development strategy benefits more from runoff control than the sprawl urban development strategy; (2) in non-flood season permeable pavements, bioretention cells, and vegetated swales decrease peak runoff forcefully and permeable pavements, bioretention cells, and green roofs are good at runoff volume retention; (3) contrary to the general opinion about the peak reduction effect of LID,

20 for partly urbanized, partly rural basins and extremely wet conditions, the implementation of LID practices delays urban peak runoff and may cause stacking of rural and urban sub-flows, leading to larger basin peaks.

\section{Introduction}

Urbanization brought numerous environmental and hydrological changes to river basins and led to severe disturbance to the natural water processes. Unwanted vegetation is removed for urban development, diminishing the vegetation interception and transpiration. Large areas of pervious native soil are replaced by impervious concrete and asphalt for human convenience, impeding runoff infiltration and subsurface water retention. Without sufficient and continuous groundwater recharge, more environmental issues occur, such as land subsidence, groundwater shortage, and water quality degradation (Ahiablame and Shakya, 2016). These human activities modify catchments from a relatively robust natural condition to a sensitive and unstable urbanized status, resulting in water scarcity in dry seasons and waterlogging or urban flooding in rain seasons (Gilroy and Mccuen, 2009; Ahiablame et al., 2012).

To solve flooding problems, the Conventional Drainage approach (CD) is widely exploited in urban areas, which adopts rapid and centralized water transfer strategy: Drainage systems are built to rapidly collect and convey the storm and wastewater from urban impervious areas to centralized municipal facilities, nearby water bodies, or downstream rural areas. The CD approach does not solve water problems such as peak flows and water quality issues, which only shifts the problems to another place to some extent. Low Impact Development (LID) is promoted as an alternative to $\mathrm{CD}$, seeking environmentally friendly solutions for current urban water 
problems. Instead of conventional centralized grey infrastructures such as pipelines and reservoirs, Low Impact Development exploits blue-green practices such as green roofs and permeable pavements to mimic the natural hydrological system and facilitate rainwater detention and natural purification processes, controlling the rainwater at the source and reducing human impact (Dietz, 2007; Gilroy and Mccuen, 2009; Bedan and Clausen, 2009; Ahiablame et al., 2012; Ulkü et al., 2018).

Since the promotion of the LID concept during the1990s, plenty of LID practices are designed and introduced in different field conditions, to realize diverse hydrological functions and ecosystem services. The most widely used LID practices include (1) Bioretention cells, also known as rain gardens or depressed green, capture runoff with thick layers of soil and lush vegetation. (2) Vegetated swales, shallow and narrow open channels to convey the rainwater, as alternative options for traditional concrete gutters and curbs. (3) Extensive, vegetated green roofs; one of the most popular LID practices because of its claimed advantages, including runoff reduction, house insulation, and ecological and aesthetic benefits. (4) Permeable pavements, a multifunction LID practice, can be flexibly incorporated in different pavement-needed surroundings, enjoying the hydrological benefits of high infiltration and detention capacity.

The effectiveness of LID practices on runoff reduction has been documented by numbers of scientific papers with field tests and simulation investigations. Bioretention cells are shown to reduce $48 \%$ to $97 \%$ of the incoming runoff volume (Chapman and Horner, 2010; DeBusk and Wynn, 2011). For extensive green roofs, the runoff reduction proportion varies a lot between $6.1 \%$ and $100 \%$ with roof slope, media type and depth, vegetation species, and the intensity and duration of rain events (VanWoert et al., 2005; Carpenter and Kaluvakolanu, 2011; Soulis et al., 2017). Hunt et al. (2010) monitored the runoff reduction of a vegetated swale for 23 precipitation events and reported that the runoff reduction proportion has a significant difference between $35 \%$ and $100 \%$ for large and small storm events. Permeable pavements were observed to reduce the runoff between $50 \%$ and $93 \%$ (Rushton, 2001; Hunt et al., 2002; Dreelin et al., 2006). Qin et al. (2013) assessed the performance of swales, permeable pavement, and green roof in a small urbanized basin using the US EPA Storm Water Management Model (SWMM) model and found all three LID practices can retain more flood volume during heavier and shorter storm events. Ahiablame et al. (2016) investigated the runoff reduction under various LID (porous pavement, rain barrel, and rain garden) implementation levels in a highly urbanized watershed with

65 the Personal Computer Storm Water Management Model (PCSWMM) and found runoff reductions from $3 \%$ to $47 \%$.

While the runoff retention performance of LID practices was extensively documented at the site or urban basin scales, few studies illustrated the influence of LID implementation in a half-rural and half-urbanized catchment at a large scale. This research is necessary, especially in watersheds where the urban areas are concentrated at the outlet. Because of the faster runoff response time of urban lands, there will be a time difference between the urban and rural sub-peaks after a precipitation event. Runoff peaks from the urban part of the basin in most cases reaches the outlet of the basin before the peak of the rural part arrives. However, implementation of LID solutions in city areas may delay the urban sub-runoff and cause more overlap of the urban and rural peaks, and therefore result in a larger basin peak. For downstream flood safety, implementation of LID needs to consider the runoff not only in urban areas but also on the whole catchment scale. That is why, this research aims to study the influence of LID implementation on the basin peaks at a catchment scale. 
To investigate the problem of peak stacking of the rural and urban peaks, case study is conducted. The SUPERFLEX conceptual model framework is used to develop a simulation model of the rainfall-runoff relationship of this partly urbanized catchment. Further urbanization of this catchment is foreseen, and to deal with the uncertainty of future urban development, scenario analysis of both LID implementation and urbanization are used to give a reliable answer to the research question. The specific objectives were to (1) investigate the different rainfall-runoff relationships of urban and rural sub-areas; (2) examine the influence of urbanization on the basin runoff; and (3) assess the influence of LID implementation on the basin runoff, especially on the overlap of urban and rural sub-flows at peak times.

85 The structure of this paper is organized as follows: The study area and data are introduced in Section 2. The methodology about the model setup and scenario design is illustrated in Section 3. The main research results regarding the effects of urbanization and LID implementation on catchment scale are shown in Section 4. Some discussions concerning the limitation of this research and recommendations for future urban development are mentioned in Section 5. And finally, the conclusions are drawn in Section 6.

\section{Study area and data}

\subsection{Study area}

The research catchment is a sub-basin of San Antonio River with $4544 \mathrm{~km}^{2}$. The City of San Antonio takes 27 $\%$ of the research catchment $\left(1209.5 \mathrm{~km}^{2}\right)$ and is located near the basin outlet as shown in Fig. 1. Several rivers and creeks, including San Antonio River, flow through San Antonio downtown and then join with Medina

95 River.

San Antonio has a transitional humid subtropical climate featuring hot and humid summers and mild to cool winters. The average annual precipitation is $737 \mathrm{~mm}$. The soil in San Antonio City mainly belongs to moderately permeable clayey soils. Edwards Aquifer is the most prolific groundwater aquifer in the study area, which provides the water for people in San Antonio. To release the stress of the Edwards Aquifer, a

100 groundwater recharge project is developed in the north part of San Antonio by holding back storm runoff in recharge zones. Except for this official groundwater recharge project, managed stormwater infiltration is not allowed in other places, to avoid groundwater pollution (The Edwards Aquifer Website, 2020). Natural stormwater infiltration will inevitably take place in rural and unpaved areas and in LID practices like permeable pavements and bioretention cells. This water will recharge the local groundwater and drains slowly to the river system.

San Antonio has separate foul sewer and stormwater systems. The precipitation collected by the stormwater pipeline system in urban areas is discharged directly to nearby water bodies without treatment. For the wastewater, three major wastewater treatment centers provide water treatment to people in San Antonio and neighboring cities, and the treated water is discharged to nearby rivers (San Antonio Water System, 2020). 


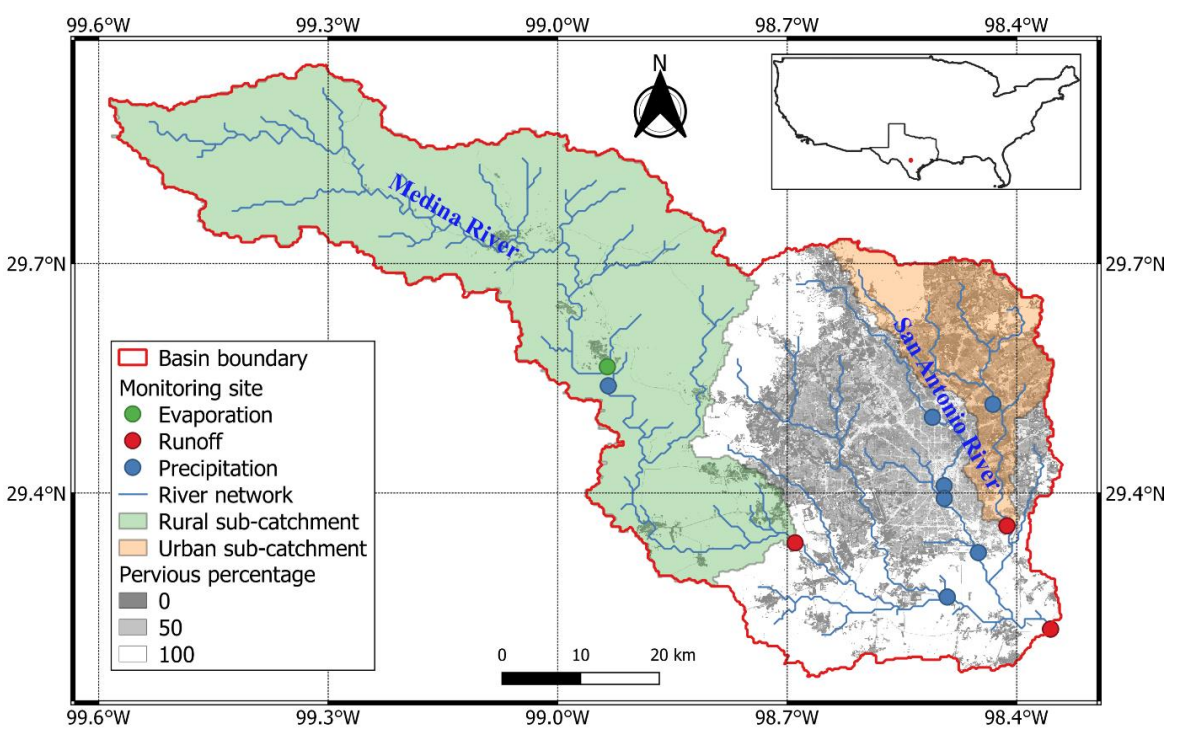

Figure 1: The locations of study catchment and two sub-catchments (The rural and urban sub-catchments are colored in green and orange, respectively). The grey areas indicate the City of San Antonio (Colstoun et al., 2017).

As for the social condition, San Antonio city is the seventh most populous city in the U.S. with more than 1.5 million residents (Ready and Montoya, 2019). It is also the fastest-growing of the top ten largest cities in the

115 United States (The City of San Antonio - Official City Website, 2020). From 2010 to 2017, San Antonio experienced a population growth rate between $1.5 \%$ and $2.0 \%$ and the city still keeps a stable demographic expansion. With this stable population increase, the urban land use of San Antonio is expected to grow at a more or less equal pace.

\subsection{Hydrological data}

120 Retrieved from the USGS website (https://www.usgs.gov/), the precipitation, evaporation, and runoff data from study catchment were collected for hydrological modeling of 600 research days, from 2017-04-12 00:00 to 2018-12-02 23:30. The first 365 days are the calibration period and the last 235 for verification. The time scale is 30 minutes to reflect the fast water response character of urban areas.

Precipitation data from 10 monitoring stations are available, and Thiessen polygons method is used to calculate

125 the total precipitation in this catchment. Evaporation data come from a meteorological station in the research area. The discharge data from three catchments (study catchment and two sub-catchments) are collected from three streamflow monitoring stations as shown in Fig. 1. Among 600 research days, the precipitation and evaporation amounts are 1335 and $1054 \mathrm{~mm}$, and the discharge is $166 \mathrm{~mm}$.

\section{Methodology}

130 To address the research problem, three urbanization and five LID implementation scenarios are designed to deal with the prediction uncertainty and alternative LID practices. SUPERFLEX conceptual model framework is adapted to a semi-distributed model with urban and rural surfaces to simulate the rainfall-runoff relationships of 
the current situation and the eight scenarios. The scenario design is introduced in this section, following the model setup.

\subsection{Scenario design}

\subsubsection{Urbanization scenarios}

According to the projected urbanization information provided by "City of San Antonio: Comprehensive Plan" (2010), there will be 1.1 million new residents in San Antonio by 2040. Since in this research current time is defined as 2017, expected population growth between 2017 and 2040 is estimated as 0.9 million new residents.

140 The government of San Antonio planned to terminate the unconstrained sprawl of the city but adopt the infill strategy and retrofit existing urban and suburban areas to attract more investment in the urban core and save the high cost of infrastructure and utility services.

Based on the information above, three urban development scenarios for 2040 were designed as shown in Table 1. Scenario A offers an extreme infill urban development situation, in which city size in 2040 will be the same as it is now. Scenario B presents a partial-infill, partial-sprawl urban development situation. In this scenario, 70 $\%$ of the new residents will live in current urban areas, while $30 \%$ of new residents will be living in new suburban areas. In scenario C, $50 \%$ of the new residents are assumed to stay in urban expansion areas, while the other $50 \%$ will infill current vacant and underutilized urban areas. Since the infill development strategy may lead to compact living space, per capita living space for scenario A is assumed to be 0.85 times the current

150 areas, and this ratio is 0.9 for scenario B, while no compact living space is assumed for scenario C.

Table 1. Urban development scenarios between 2017 and 2040, based on City of San Antonio: Comprehensive Plan (2010)

\begin{tabular}{l|l|ll|ll|l}
\hline Scenarios & $\begin{array}{l}\text { Total } \\
\text { residents }\end{array}$ & $\begin{array}{l}\text { Percentage of new } \\
\text { residents following } \\
\text { the infill } \\
\text { development [\%] }\end{array}$ & $\begin{array}{l}\text { Residents } \\
\text { in current } \\
\text { urban areas } \\
\text { [million] }\end{array}$ & $\begin{array}{l}\text { Percentage of new } \\
\text { residents following } \\
\text { the sprawl } \\
\text { development [\%] }\end{array}$ & $\begin{array}{l}\text { Residents in } \\
\text { urban } \\
\text { expansion } \\
\text { areas [million] }\end{array}$ & $\begin{array}{l}\text { Compact } \\
\text { factor for } \\
\text { living } \\
\text { space }\end{array}$ \\
\hline $\begin{array}{l}\text { Current } \\
(2017)\end{array}$ & 1.5 & - & 1.5 & - & - & - \\
A $(2040)$ & 2.4 & 100 & 2.4 & 0 & 0 & \\
B (2040) & 2.4 & 70 & 2.13 & 30 & 0.27 & 0.85 \\
C $(2040)$ & 2.4 & 50 & 1.95 & 50 & 0.45 & 0.9 \\
\hline
\end{tabular}

\subsubsection{LID implementation scenarios}

According to local regulations, the implementation of LID is not strictly mandatory for every development or

155 redevelopment project, and there is great flexibility in the selection of LID practices. Therefore, this research will adopt four most common and typical LID practices to design five LID implementation scenarios based on the conventional urban development scenario $\mathrm{C}$. The first four scenarios assume moderate LID implementations, as $15 \%$ of the precipitation on urban impervious (grey) surfaces will be collected by a single type of LID practice - bioretention cells, vegetated swales, extensive green roofs, and permeable pavement. This will allow

160 us to compare the different hydrological performances of these LID practices.

The last scenario assumes a wide scale LID implementation, as $50 \%$ of the precipitation on urban impervious (grey) surfaces will be conveyed by mixed LID practices (bioretention cells, $15 \%$; vegetated swales, $15 \%$; extensive green roof, $5 \%$; permeable pavement, $15 \%$ ), to provide an optimistic and flexible LID implementation plan. Green roofs and permeable pavements serve the area where they are constructed; the ratio 

both collect and retain stormwater from a larger contributing area. Besides, the cascading connections among these LID practices were designed based on realistic construction considerations as shown in Fig. 2.

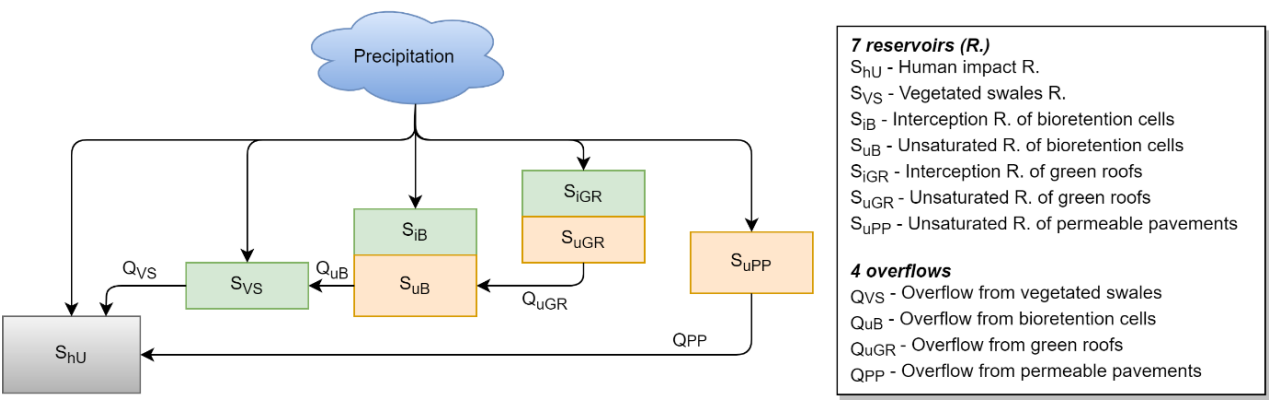

Figure 2: Cascade connection routes between four LID practices in the mixed LID scenario.

\subsection{Hydrological model}

To avoid the drawbacks of too complex models including high-data requirement, equifinality, and model uncertainty, and to distinguish rural and urban areas in the same catchment, a conceptual flexible SUPERFLEX (Fenicia et al., 2011) hydrological modeling framework is adapted in a semi-distributed model with the urban or rural surfaces. While SUPERFLEX has been used to simulate the rainfall-runoff relationships in different natural landscapes, it has not yet been employed in a highly urbanized catchment. That is why, several urban water processes, as well as four LID modules (bioretention cells, green roofs, bioswales, and permeable pavements) had to be formulated and added to the SUPERFLEX framework.

\subsubsection{Semi-distributed model setup}

The hydrological model starts from two simple lumped pre-models, one for a rural and one for an urban subcatchment, respectively. The dominant water processes will be identified from lumped models and inherited by semi-distributed models for the simulation of the whole study catchment.

For parameter calibration, the initial range of each parameter was given based on empirical values (Gharari et al., 2014). Then, random parameter sets were sampled between the maximum and minimum limitations with the Monte Carlo method, and more complex models with more parameters were tested with larger numbers of parameter sample sets to ensure the calibration scale as "fair" as possible. For semi-distributed models, two constraints are exploited to reduce the risk of unrealistic combinations of parameters (Hrachowitz et al., 2014): (1) the maximum percolation velocity in urban areas is assumed to be smaller than it in rural areas $\left(\mathrm{P}_{\max , \mathrm{R}}>\right.$ $\left.\mathrm{P}_{\max , \mathrm{U}}\right)$. (2) the water storage depth in the unsaturated zone in urban areas is assumed to be smaller than it in rural areas $\left(S_{u m a x, R}>S_{u m a x, U}\right)$. 


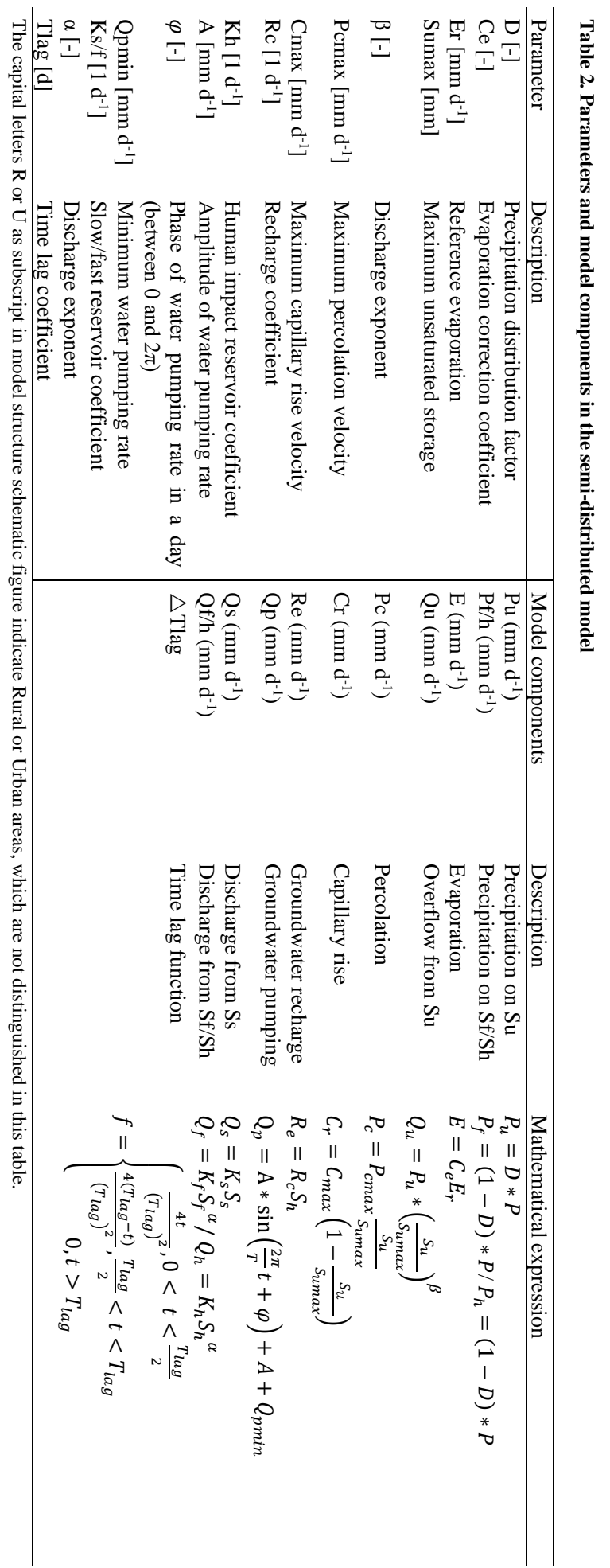


The model structure was determined from six generations of semi-distributed, six-bucket to eight-bucket models based on the runoff verification results. The verified Nash-Sutcliffe Efficiencies (NSEs) and the correlation coefficient $\left(\mathrm{R}^{2}\right)$ are calculated as accuracy indexed. Appropriate model structure and parameters are indicated by the optimal NSE and $\mathrm{R}^{2}$, and the variance of the verified NSEs is used to assess the precision. The final selection of the semi-distributed model is a six-bucket model, the schematic figure and mathematical expressions of which are shown in Fig. 3 and Table 2. After the selection of model structure, an appropriate parameter set was selected considering the matching extent of modeled and observed runoff distributions with the quantile-quantile plot (QQ plot) and the model performance in rural and urban sub-catchments.

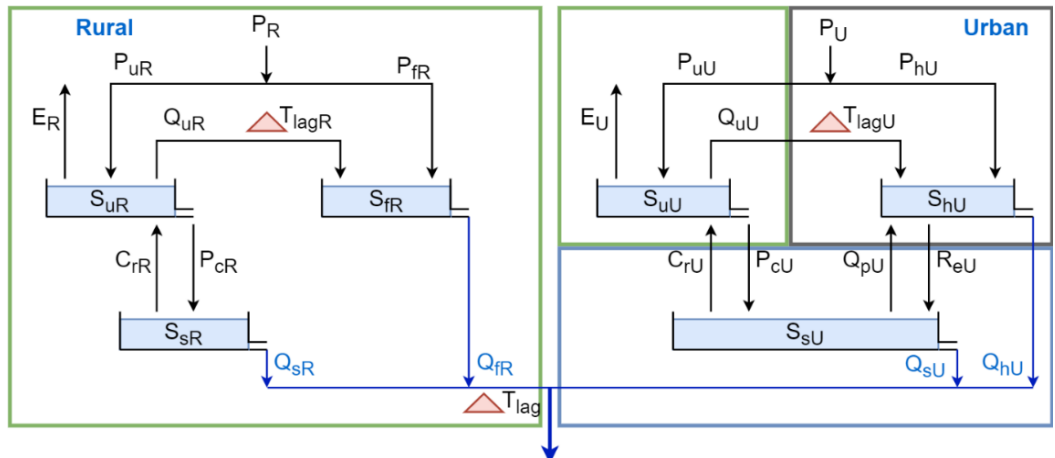

Figure 3: Schematic figure of semi-distributed model structure. The rural module depicts a fully natural hydrological picture with three reservoirs, including Unsaturated reservoir $\left(S_{\mathrm{uR}}\right)$, Fast reacting reservoir $\left(S_{\mathrm{fR}}\right)$, and Slow reacting groundwater reservoir $\left(S_{\mathrm{sR}}\right)$. The urban module consists of three parts, urban green surface, urban grey surface, and underground parts, corresponding to three reservoirs, Unsaturated reservoir $\left(S_{\mathrm{uU}}\right)$, Human impact reservoir $\left(S_{\mathrm{hU}}\right)$, and Slow reacting reservoir $\left(\mathrm{S}_{\mathrm{su}}\right)$ respectively. The hydrological processes and their mathematical expressions are indicated in Table 2.

\subsubsection{The expression of urban development in the model}

In the semi-distributed model, three urbanization scenarios are expressed with two parameters, 1) the proportion of urban areas in the whole catchment and 2) the proportion of urban grey areas in urban areas (1-D), under the assumption that the degree of urban construction (including water drainage system) and population density are assumed to be consistent in the city. The numerical features of the three urbanization scenarios are shown in Table 3.

Table 3. Parameter calculation table of Urbanization Scenarios

\begin{tabular}{|c|c|c|c|c|c|c|}
\hline & Num & Calculating formula & $\begin{array}{l}\text { Current } \\
(2017)\end{array}$ & $\begin{array}{l}\text { Scenario } \\
\text { A (2040) }\end{array}$ & $\begin{array}{l}\text { Scenario } \\
\text { B (2040) }\end{array}$ & $\begin{array}{l}\text { Scenario } \\
\text { C (2040) }\end{array}$ \\
\hline Total residents (million) & (1) & - & 1.5 & 2.4 & 2.4 & 2.4 \\
\hline $\begin{array}{l}\text { The residents in current } \\
\text { urban areas (million) }\end{array}$ & (2) & $\begin{array}{l}\text { According to scenarios } \\
\text { design }\end{array}$ & 1.5 & 2.4 & 2.13 & 1.95 \\
\hline $\begin{array}{l}\text { The residents in urban } \\
\text { expansion areas (million) }\end{array}$ & (3) & $\begin{array}{l}\text { According to scenarios } \\
\text { design }\end{array}$ & 0 & 0 & 0.27 & 0.45 \\
\hline Per capita urban areas $(\mathrm{m} 2)$ & (4) & $\begin{array}{l}\text { Current urban area / } \\
\text { (2) }\end{array}$ & 806.3 & 504.0 & 567.8 & 620.3 \\
\hline Expansion areas $(\mathrm{km} 2)$ & (5) & $(3) *(4)$ & 0 & 0 & 153.3 & 279.1 \\
\hline $\begin{array}{l}\text { Total urban areas after } \\
\text { expansion }(\mathrm{km} 2)\end{array}$ & (6) & $\begin{array}{l}\text { Current urban area } \\
+(5)\end{array}$ & 1209.5 & 1209.5 & 1362.8 & 1488.6 \\
\hline $\begin{array}{l}\text { The proportion of urban } \\
\text { areas in study catchment }\end{array}$ & (7) & (6) / Catchment area & 0.266 & 0.266 & 0.300 & 0.328 \\
\hline Distribution factor of grey & (8) & Model result for current & 0.170 & 0.232 & 0.218 & 0.221 \\
\hline
\end{tabular}


areas (1-D)

Total urban grey areas $(\mathrm{km} 2)$

Per capita urban grey areas (m2)

Compact factor of per capita urban grey areas (-)

The shaded numbers are used to adapt the model for urbanization scenarios A, B, and C

condition; $(9) /(6)$ for

Scenario $A, B, C$

(9)

condition; $(10) *(1)$ for

Scenario $A, B, C$

(10) (9)/(1) for current

condition;

$\left(10 \_\right.$current $) *(11)$ for

Scenario $A, B, C$

(11) Assumption

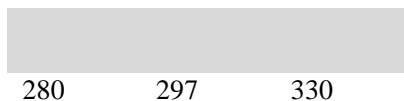

117

124

137

$\begin{array}{lll}0.85 & 0.9 & 1\end{array}$

\subsubsection{The expression of LID practices in the model}

The expression of LID in the semi-distributed model follows two procedures. First, the hydrological routes of LID practices were designed and fit in the urban module. And then, reasonable values were assumed for those involved parameters based on relevant literatures, realistic field test results, and data from local government files (Carter and Jackson, 2007; Carter and Rasmussen, 2006; Collins et al., 2008; Hunt et al., 2008; Li et al., 2009; San Antonio River Authority, 2015; San Antonio Water System, 2020; Van Seters et al., 2006;). The schematic model figure of four LID practices in the urban SUPERFLEX module is shown in Fig. 4. The mathematical expressions of hydrological routes and the quantitative comparison of the parameter values are shown in Table 5 .
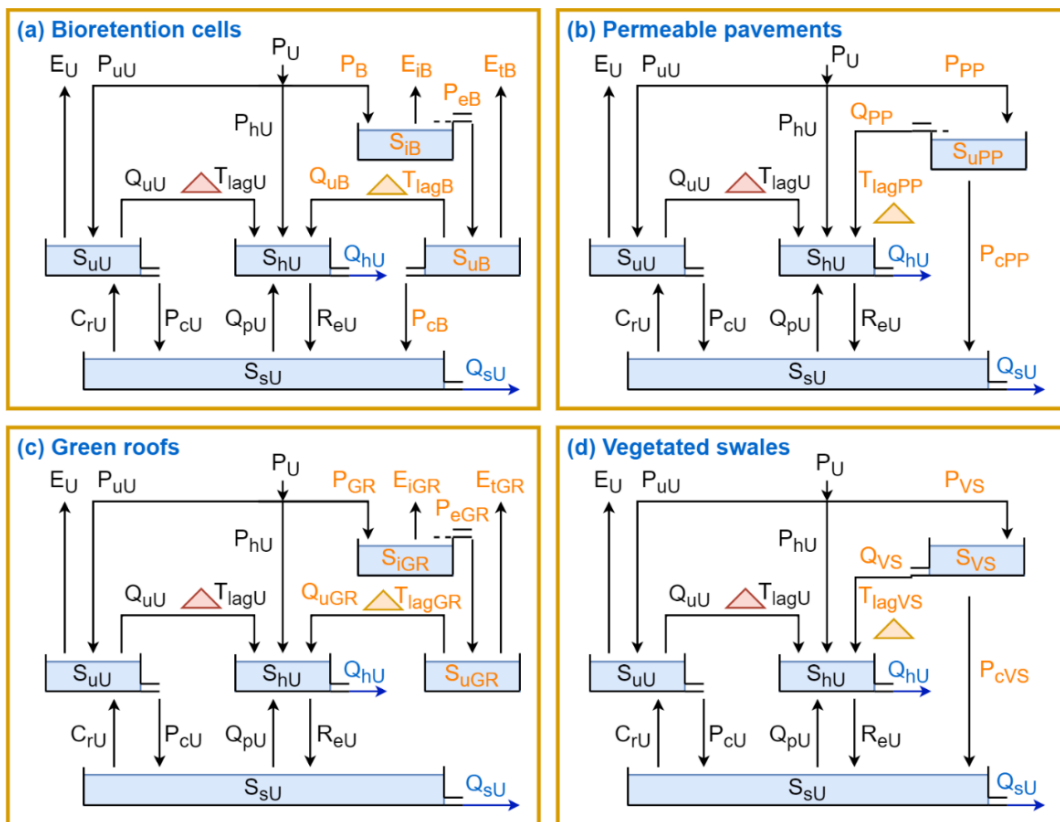

Figure 4: Schematic figure of updated urban model components for four single LID scenarios. (a) In bioretention cells module, Interception reservoir ( $\mathrm{SiB}$ ) and Unsaturated reservoir $(\mathrm{SuB})$ are designed. (b) Permeable Pavement reservoir (SuPP) is added in permeable pavements module. (c) For vegetated swales module, the Vegetated Swales reservoir (SVS) is added. (d) Interception reservoir (SiGR) and Unsaturated reservoir (SuGR) are created for the extensive green roofs module. The LID relevant hydrological processes and their mathematical expressions are indicated in Table 4. 
Table 5. The parameter values of four LID practices

\begin{tabular}{lllllll}
\hline & $\mathrm{D}_{\mathrm{LID}}{ }^{\mathrm{a}}[-]$ & $\mathrm{A}_{\mathrm{R}}^{\mathrm{b}}[-]$ & $\mathrm{I}_{\max , \mathrm{LID}}[\mathrm{mm}]$ & $\mathrm{S}_{\mathrm{umax}, \mathrm{LID}}[\mathrm{mm}]$ & $\mathrm{T}_{\text {lagLID }}[-]$ & $\mathrm{K}_{\mathrm{VS}}[-]$ \\
\hline Bioretention cell & $\mathrm{D}_{\mathrm{B}}$ & $\mathrm{A}_{\mathrm{R}, \mathrm{B}} \geq 1$ & $3.5 / \mathrm{A}_{\mathrm{R}} * \mathrm{D}_{\mathrm{B}}$ & $300 / \mathrm{A}_{\mathrm{R}} * \mathrm{D}_{\mathrm{B}}$ & 13 & - \\
Vegetated swale & $\mathrm{D}_{\mathrm{VS}}$ & $\mathrm{A}_{\mathrm{R}, \mathrm{VS}} \geq 1$ & - & - & 11 & 0.34 \\
Green roof & $\mathrm{D}_{\mathrm{GR}}$ & 1 & $3.1 * \mathrm{D}_{\mathrm{GR}}$ & $42 * \mathrm{D}_{\mathrm{GR}}$ & 3 & - \\
Permeable Pavement & $\mathrm{D}_{\mathrm{PP}}$ & 1 & $4 * \mathrm{D}_{\mathrm{PP}}$ & $120 * \mathrm{D}_{\mathrm{PP}}$ & 11 & - \\
\hline
\end{tabular}

The parameters, $\mathrm{D}_{\mathrm{LID}}{ }^{\mathrm{a}}$ and $\mathrm{A}_{\mathrm{R}}{ }^{\mathrm{b}}$, depend on the concrete LID implementation scenarios

\section{Results}

\subsection{Different hydrological responses of urban and rural areas}

The simulated rainfall-runoff relationship under the current condition is shown in Fig. 5, with NSE as 0.68 and $\mathrm{R}^{2}$ as 0.90 during the calibration period and 0.69 and 0.84 during the verification period. The observed total basin runoff is $166 \mathrm{~mm}$ in 600 research days. And it is $166 \mathrm{~mm}$ for the model result, in which urban districts (27 $\%$ of the catchment areas) produce $63 \%$ of total runoff; only $37 \%$ of total runoff is discharged from rural areas (73\% of the catchment areas). In general, rural runoff is more stable than urban runoff. Urban areas generate peak runoff frequently, no matter in dry or rainy seasons, while in rural areas the peak runoffs appear less often with lower summits.

With the parameter calibration results as shown in Table 6, the different hydrological characters of rural and urban areas can be further explained: First, the precipitation distribution factor for the unsaturated zone (D) and the maximum unsaturated storage depth (Sumax) in the rural module are larger than them in the urban module, which creates larger water retention capacity in rural areas; Second, the larger evaporation coefficient (Ce) in rural areas leads to massive water evaporation, which can be explained by the favorable vegetation condition in rural areas; Third, although the percolation capacity is similar in urban and rural areas with close the maximum percolation velocities (Pcmax), because of the dense vegetation the capillary rise capacity in rural areas is far larger than it in urban areas with higher maximum capillary rise velocity (Cmax); Finally, the value for parameter Ks, indicating the flow rate of deep groundwater, in rural areas is larger than it in urban areas, which indicates a stable and fluent groundwater flow in rural areas. All these four hydrological differences lead to a more stable rural runoff than urban runoff.

Table 6. Parameter values in the current model

\begin{tabular}{|c|c|c|c|c|c|c|c|c|}
\hline Para. & D [-] & $\mathrm{Ce}[-]$ & $\begin{array}{l}\text { Sumax } \\
{[\mathrm{mm}]}\end{array}$ & $\begin{array}{l}\text { Pcmax } \\
{\left[\mathrm{mm} \mathrm{d}^{-1}\right]}\end{array}$ & $\begin{array}{l}\mathrm{Cmax} \\
{\left[\mathrm{mm} \mathrm{d}^{-1}\right]}\end{array}$ & $\operatorname{Rc}\left[1 \mathrm{~d}^{-1}\right]$ & $\begin{array}{l}\text { A [mm } \\
\left.\mathrm{d}^{-1}\right]\end{array}$ & $\begin{array}{l}\text { Qpmin } \\
{\left[\mathrm{mm} \mathrm{d}^{-1}\right]}\end{array}$ \\
\hline Rural & 0.98 & 2.7 & 186 & 4.9 & 0.7 & - & - & - \\
\hline Urban & 0.83 & 1.1 & 51 & 4.8 & 0.1 & 1.5 & 0.65 & 0 \\
\hline Para. & beta [-] & $\mathrm{Kf} / \mathrm{Kh}\left[\mathrm{d}^{-1}\right]$ & $\mathrm{Ks}\left[\mathrm{d}^{-1}\right]$ & alpha [-] & Tlag [d] & $\begin{array}{l}\text { Tlag for rural } \\
\text { sub-flow [d] }\end{array}$ & $\varphi[-]$ & \\
\hline Rural & 6.5 & 0.88 & 0.004 & 8.0 & 1.75 & -0.83 & - & \\
\hline Urban & 1.6 & 0.51 & 0.002 & 1.5 & 1.75 & - & 2.2 & \\
\hline
\end{tabular}



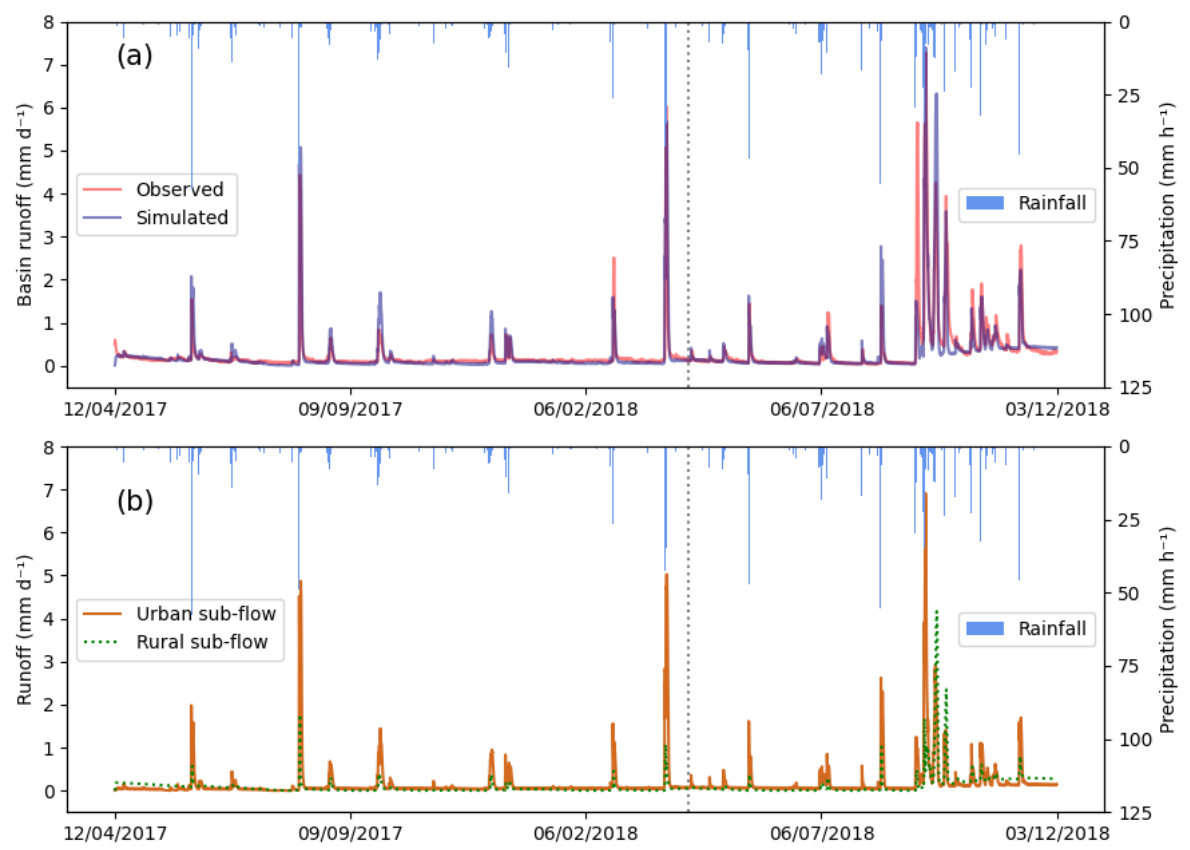

Figure 5: Model result of the rainfall-runoff relationship in the current simulation. The left and right sides of the dotted vertical line indicate calibration and verification periods, respectively. (a) The observed and simulated total basin runoff and (b) the simulated rural and urban sub-flows.

\subsection{Urbanization influences on basin runoff}

The simulated total runoff volumes and the maximum peak values in 600 research days for the three urbanization scenarios are shown in Table 7. From the view of total runoff volume, all three urbanization plans increased the total basin runoff at different levels. Scenario $\mathrm{C}$, with the highest level of urban sprawl development (50\% of new residents following the infill development) without the compact of per capita living space, brought $14 \%$ additional total basin runoff compared to the current situation. For scenarios B and A, in which $70 \%$ and $100 \%$ of the new residents following the infill development and with the compact factors 0.9 and 0.85 , these growth rates are $8.7 \%$ and $2.7 \%$ respectively.

Table 7. The simulation results of total runoff volumes and the maximum peak runoff values for three conventional urban development scenarios

\begin{tabular}{lllll}
\hline & Current & Scenario A & Scenario B & Scenario C \\
\hline Total runoff volume in research period $[\mathrm{mm}]$ & 160 & 164 & 174 & 183 \\
Increase proportion of the total runoff $[-]$ & - & $2.7 \%$ & $8.7 \%$ & $14 \%$ \\
\hline The maximum peak runoff $\left[\mathrm{mm} \mathrm{d}^{-1}\right]$ & 7.4 & 7.1 & 8.0 & 8.6 \\
Increase proportion of the maximum peak runoff $[-]$ & - & $-4.3 \%$ & $7.5 \%$ & $16 \%$ \\
\hline
\end{tabular}

As for the peak runoffs, Fig. 6 shows the simulated total basin runoffs for three urbanization scenarios and the

270 current situation. It can be found that, for most peak runoffs in the dry season, all three urbanization plans brought obvious increases, among which scenario $\mathrm{C}$ always brought the largest peak runoffs followed by scenarios B and A consecutively. 


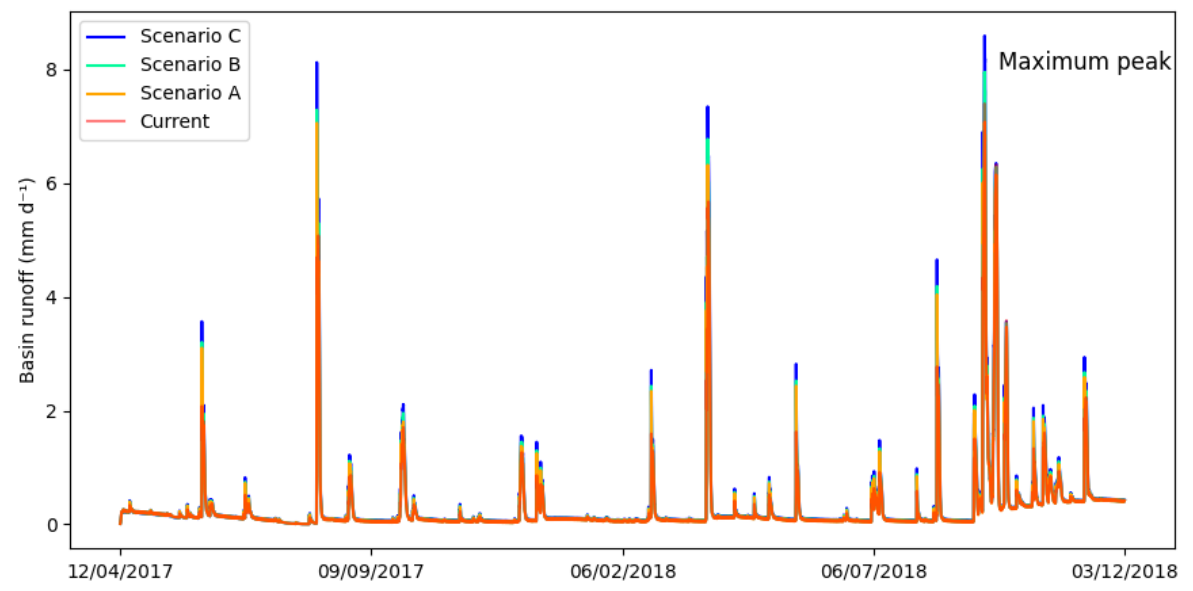

Figure 6: The simulated total basin runoffs for three urbanization scenarios and current situation. The total runoff volumes in 600 research days and the maximum peak runoffs happening on $10^{\text {th }}$ Sep. 2018 are displayed in Table 7.

For the maximum peak runoff happened in the rainy season $\left(10^{\text {th }}\right.$ Sep. 2018), the peak value increased by $16 \%$ and $7.5 \%$ for scenario $\mathrm{C}$ and $\mathrm{B}$, as shown in Table 7. However, in scenario A, as a full infill urbanization scenario without urban expansion, the maximum peak runoff unexpectedly declines by $4.3 \%$. This is because the intensive rainfall events in the rainy season filled up the water retention capacity in rural and urban green areas, and the maximum peak is not only generated from the urban grey areas but also from large areas of urban green surfaces. As shown in Fig. 7, the maximum peak runoff experienced two summits in succession from $9^{\text {th }}$ Sep to $11^{\text {th }}$ Sep. The small lower peak I was mainly contributed by the urban grey surface with fast hydrological response, and in this time, urban green areas were getting saturated and generating stable and rising outflow. When it came to summit II, the flow from urban green surfaces reached the peak and became the main contribution of the summit II. In urbanization scenario A, part of urban green areas was replaced by urban grey areas to meet the needs of population growth, and therefore the runoff of the latter summit II is partially moved forward and superimposed on the previous summit I, which causes the decrease of the latter summit II. This phenomenon also occurred on the next peak happening on $17^{\text {th }}$ Sep and caused a less peak in urbanization scenario A than the current situation, but the only difference is that the runoff generated from the almost saturated rural places played a more significant role for this peak event. 
(a)

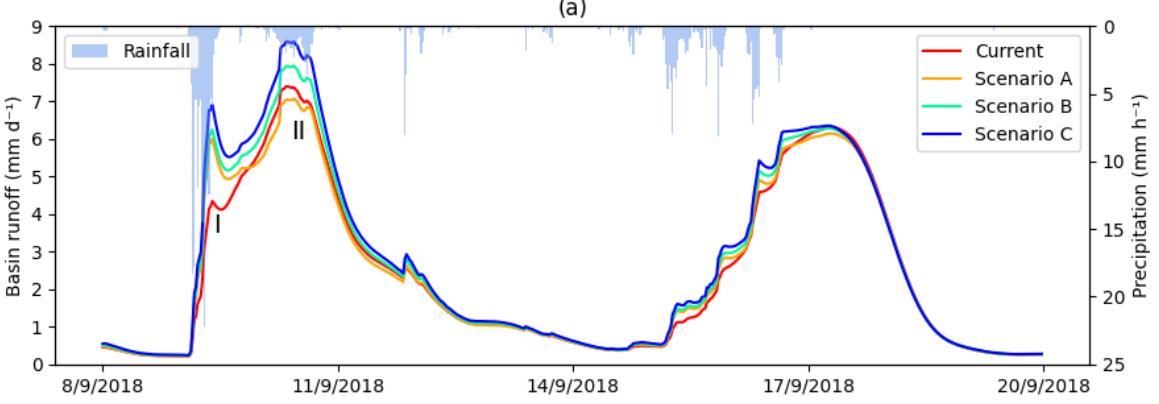

(b)

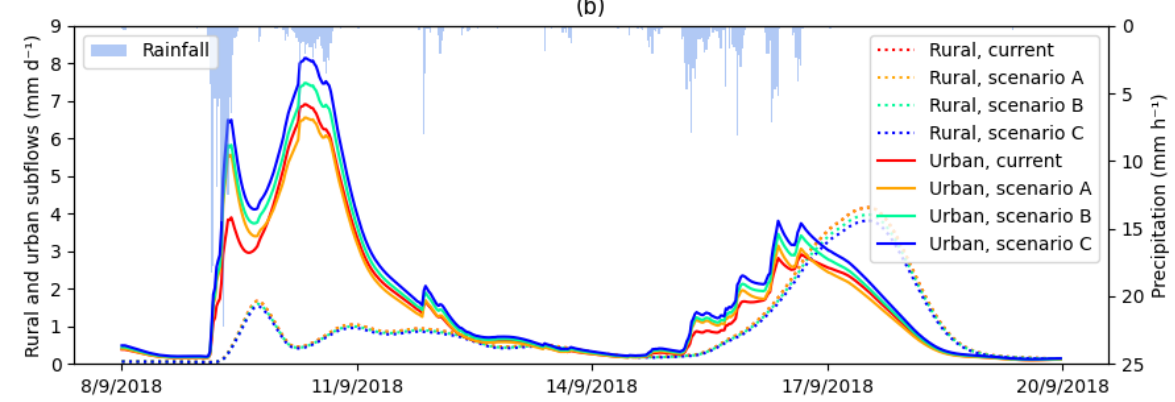

Figure 7: (a) Two successive total basin peaks in flood season as the maximum peak in 600 research days and its following peak, in which the maximum basin peak experienced two summits (I and II), and (b) their rural and urban sub-flows in three urbanization scenarios and current situation.

Overall, the infill urban development strategy is more helpful in basin runoff control for both total volumes and peak values than the sprawl urban development strategy. And secondly, even though urbanization inevitably brings the growth of basin runoff volume, the peak value of total basin runoffs can be reduced by adjusting the areas of permeable and impermeable surfaces, as the faster runoff can help to spread the peak over a longer period of time, hence reduce peaks in the total runoff.

\subsection{LID performance in the non-flood season}

The time series of forecast runoff in five LID scenarios and the Conventional urban Development scenario (CD scenario $\mathrm{C}$, following a half-infill and half-expansion urban development strategy) are shown in Fig. 8 . Compared to the CD scenario $\mathrm{C}$, all the five LID scenarios significantly reduced most peaks, except for several large peak runoffs happening in flood season around Sep. 2018, which will be discussed in section 4.4. 

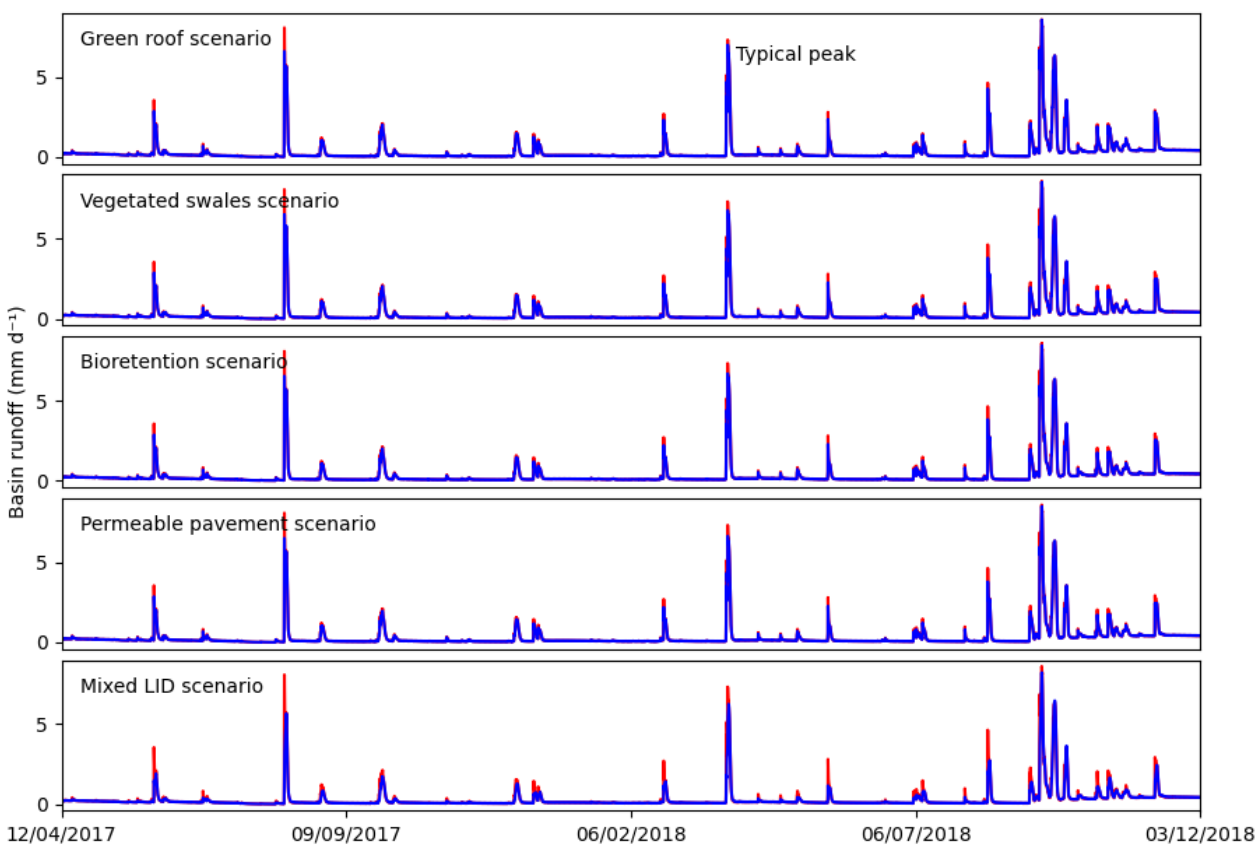

Figure 8: Comparison of the total basin runoffs in five LID scenarios (blue lines) and the CD scenario C (red line) during 600 research days. The total runoff volumes and the typical peak values are displayed in Table 8. Figure 9 shows a zoom in on the typical peak event happening on $2^{\text {th }}$ Mar. 2018.

The third maximum peak runoff in 600 research days happening on $29^{\text {th }}$ Mar. 2018, non-flood season is selected as the typical peak runoff to further reveal the LID performance on peak runoff reduction in the non-flood season as shown in Fig. 9. Sharing a similar feature with other peak runoffs, the typical peak experiences two times of summit I and II. The LID practices always reduce the first summit more significantly than the second one. This is because the first summit I is mainly generated by urban grey areas with rapid hydrological response, which is the domain of LID practices. However, the second summit II is mainly generated by large areas of urban green surfaces with slow hydrological response, and therefore the LID practices have limited influence on summit II.

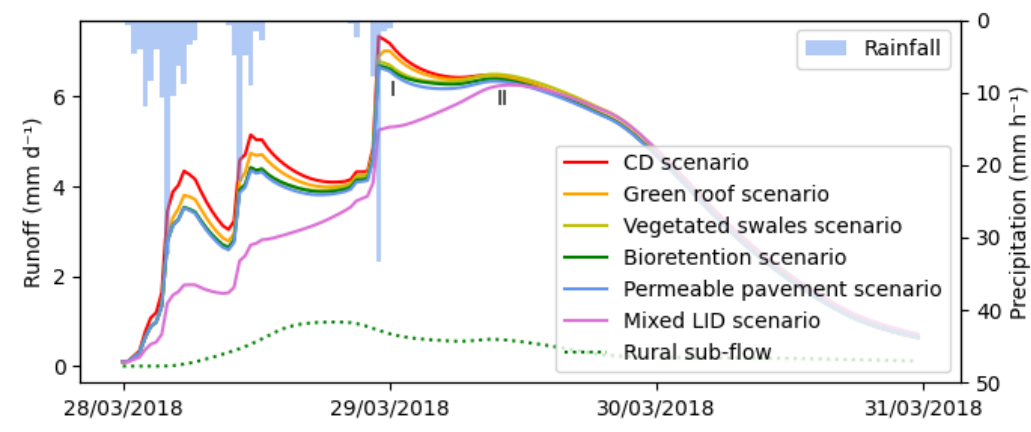

Figure 9: The typical total basin peak runoffs happening on $29^{\text {th }}$ Mar. 2018 and the rural sub-flow in five LID and one CD scenarios. The values of summit I and II of the typical peak are illustrated in Table 8 
320 The modelled total basin runoff volume and two summit values of the typical total basin peak runoff in five LID and one CD scenarios are shown in Table 8.

Table 8. The simulation results of total basin runoff volumes in 600 research days and two summit values of the typical total basin peak runoff in six LID scenarios

\begin{tabular}{|c|c|c|c|c|c|c|}
\hline Scenarios & $\mathrm{CD}$ & $\begin{array}{l}\text { Green } \\
\text { roof }\end{array}$ & $\begin{array}{l}\text { Vegetated } \\
\text { swales }\end{array}$ & Bioretention & $\begin{array}{l}\text { Permeable } \\
\text { pavement }\end{array}$ & $\begin{array}{l}\text { Mixed } \\
\text { LID }\end{array}$ \\
\hline Total basin runoff volume [mm] & 182 & 178 & 180 & 178 & 178 & 170 \\
\hline Decrease proportion of the total runoff [-] & - & $2.3 \%$ & $1.0 \%$ & $2.4 \%$ & $2.5 \%$ & $6.9 \%$ \\
\hline $\begin{array}{l}\text { Summit I of the typical peak runoff }\left[\mathrm{mm} \mathrm{d}^{-}\right. \\
\left.{ }^{-}\right]\end{array}$ & 7.3 & 7.0 & 6.8 & 6.7 & 6.6 & 5.3 \\
\hline Decrease proportion of the summit I [-] & - & $4.4 \%$ & $7.6 \%$ & $8.8 \%$ & $9.5 \%$ & $28.3 \%$ \\
\hline $\begin{array}{l}\text { Summit II of the typical peak runoff }\left[\mathrm{mm} \mathrm{d}^{-}\right. \\
\left.{ }^{1}\right]\end{array}$ & 6.48 & 6.47 & 6.50 & 6.39 & 6.34 & 6.26 \\
\hline Decrease proportion of the summit II [-] & - & $0.2 \%$ & $-0.2 \%$ & $1.4 \%$ & $2.2 \%$ & $3.5 \%$ \\
\hline
\end{tabular}

The specific runoff reduction amounts contributed by each hydrological function in four single LID scenarios

are listed in Table 9.

Table 9. Specific urban water balance components in 4 single LID practice scenarios in 600 research days

\begin{tabular}{lllllll}
\hline & & Prec. & Evap. & Infil. & Overflow & Storage \\
\hline Bioretention & Amount $(\mathrm{mm})$ & 437 & 94 & 238 & 70 & 35 \\
cell & Ratio & $100 \%$ & $22 \%$ & $55 \%$ & $16 \%$ & $8 \%$ \\
Green roof & Amount $(\mathrm{mm})$ & 437 & 188 & - & 160 & 89 \\
& Ratio & $100 \%$ & $43 \%$ & - & $37 \%$ & $20 \%$ \\
Vegetated & Amount $(\mathrm{mm})$ & 437 & - & 110 & 328 & 0 \\
swale & Ratio & $100 \%$ & - & $25 \%$ & $75 \%$ & 0 \\
Permeable & Amount $(\mathrm{mm})$ & 437 & - & 383 & 38 & 16 \\
pavement & Ratio & $100 \%$ & - & $88 \%$ & $8.6 \%$ & $3.7 \%$ \\
\hline
\end{tabular}

\subsubsection{The performance of bioretention cell scenario}

Bioretention cells have significant reduction effects on both total runoff volume and peak runoff values, second only to the permeable pavements. The total basin runoff was reduced by $2.4 \%$ from $182 \mathrm{~mm}$ to $178 \mathrm{~mm}$ in 600 research days. As for peak values, bioretention cells produced considerable reduction on the summit I of the typical peak with a removal proportion as $8.8 \%$ from $7.3 \mathrm{~mm}$ to $6.7 \mathrm{~mm}$, and the robustness of bioretention cells is also satisfactory resulting in a $1.4 \%$ reduction ratio for the summit II.

The strong runoff reduction ability of bioretention cells ascribes to the rapid water infiltration between soil granules and a large volume of water transpiration by lush vegetation. According to the simulation results shown in Table $9,55 \%$ of the precipitation falling on bioretention cells infiltrated into the underground, and $22 \%$ of the rainwater evaporated. Then, $8 \%$ of rainwater was retained in bioretention cells, and finally, the overflow from bioretention cells was only $16 \%$.

\subsubsection{The performance of permeable pavement scenario}

Permeable pavements show the best hydrological performance on basin runoff reduction among the four LID practices. In the permeable pavement scenario, the total runoff volume declined $2.5 \%$ from $182 \mathrm{~mm}$ to $178 \mathrm{~mm}$, and the two summits of typical peak runoff were reduced by $9.5 \%$ and $2.2 \%$ respectively. Even though sharing a similar total runoff volume reduction with bioretention cells, permeable pavements better reduced peak runoffs. 
In 600 research days, permeable pavements generated the least overflow, only $8.6 \%$ of the total input rainwater, as shown in Table 9. Almost $90 \%$ of the rainwater consumption of permeable pavements depends on the infiltration because additional stormwater retention space is available in the subbase, the base and between the permeable pavers or in the porous asphalt pores. Since the large water retention capacity and forceful peak runoff reduction ability, bioretention cells and permeable pavements can be seen as the most effective LID practices for urban flood control and for releasing pressure on the urban drainage system.

\subsubsection{The performance of vegetated swale scenario}

Vegetated swales achieved an appreciable peak runoff reduction similar to bioretention cells and permeable pavements. As shown in Table 8, vegetated swales decreased $7.6 \%$ of the summit I of typical peak runoff. But the sustainability of this peak runoff reduction ability is weak: rather than exhaustively consuming, vegetated swales delayed the runoff of the first summit I till the second one, which caused a larger summit II.

As for the retention of total runoff volume in the long term, the performance of vegetated swales was not outstanding. During 600 research days, only $1 \%$ of the total runoff volume was preserved. For the $437 \mathrm{~mm}$ stormwater conveyed by vegetated swales, $75 \%$ of the rainwater was discharged to the urban drainage system, and only $25 \%$ of the total rainfall was absorbed by the soil layer. It can be explained by the fast water transportation mechanism of vegetated swales. Without sufficient water retention capacity, vegetated swales do

360 not support stable and continuous infiltration. Therefore, the total runoff reduction volume of vegetated swales is distinctly smaller than the other three test LID practices.

\subsubsection{The performance of extensive green roof scenario}

The extensive green roofs brought about the least peak runoff reduction among four test LID practices. Two summits of typical peak runoff were reduced by $4.4 \%$ and $0.2 \%$, which are far less than in other scenarios. However, the reduction on total runoff volume of green roof scenario is more satisfactory with the reduction ratio as $2.3 \%$, which is close to this ratio in permeable pavement $(2.5 \%)$ and bioretention cell $(2.4 \%)$ scenarios. According to the specific runoff retention amount, the water consumption of green roofs relied on evaporation (43\%) and water storage (20\%), while $37 \%$ of the rainwater overflowed.

The significant difference between runoff volume and peak value reductions ascribes to the small water retention capacity of green roofs: Although the green roof shares a similar model structure to bioretention cells with vegetation and soil, the soil thickness of extensive green roofs is small and no infiltration process happen on rooftops. The small water retention capacity of green roofs leads to a sensitive hydrological performance to the predecessor rains: If there are no or fewer predecessor rains, the green roof can still play a role in peak runoff reduction; however, when it comes to rainy seasons, the green roof will be easily filled up by the frequent storm events and lose its peak runoff reduction function.

\subsubsection{The performance of mixed LID scenario}

The mixed LID scenario is the most forceful LID scenario to reduce both the peak runoff and the total runoff volume. The typical peak runoff was decreased considerably in the mixed LID scenario, as $28 \%$ for the submit I and $3.5 \%$ for the submit II. As for the total runoff volume in 600 research days, the mixed LID practices restricted the generation of total basin runoff volume from $182 \mathrm{~mm}$ to $170 \mathrm{~mm}$ with a $6.9 \%$ reduction ratio. 
Except for the large contribution area of LID practices, another advantage of the mixed LID scenario attributes to the cascade connection among LID practices, which adjusts the unbalanced water capture capacities of different LID practices, reinforcing the robustness of the LID system.

Table 10 shows the specific water retention amounts of 4 LID practices in the mixed LID scenario. The evaporation of green roofs and bioretention cells, and the infiltration of bioretention cells and permeable pavements realized abundant water uptakes. In the mixed LID scenario, bioretention cells became the most effective and efficient LID practices among four test LID practices with the largest runoff volume consumption and fewer construction areas. Comparing the hydrological performances of bioretention cells in single bioretention cells and mixed LID scenarios, with more water input and less construction area, the water retention ability of bioretention cells, especially the evaporation, was better developed with almost the same proportion of overflow.

Table 10. Specific urban water balance components of 4 LID practices in mixed LID scenario in 600 research days

\begin{tabular}{|c|c|c|c|c|c|c|c|c|}
\hline & & Prec $^{a}$ & Inflow $^{\mathrm{b}}$ & Evap & Infil & Storage & Overflow & Consume \\
\hline \multirow[t]{2}{*}{ Green roof $(5 \%)$} & Amount (mm) & 437 & - & 255 & - & 2.5 & 180 & 257 \\
\hline & Ratio & - & - & $58 \%$ & - & $0.6 \%$ & $41 \%$ & $49 \%$ \\
\hline \multirow{2}{*}{$\begin{array}{l}\text { Bioretention } \\
(15 \%)\end{array}$} & Amount (mm) & 437 & 60 & 257 & 133 & 25 & 82 & 415 \\
\hline & Ratio & $88 \%$ & $12 \%$ & $52 \%$ & $27 \%$ & $5.0 \%$ & $17 \%$ & $84 \%$ \\
\hline \multirow{2}{*}{$\begin{array}{l}\text { Vegetated } \\
(15 \%)\end{array}$} & Amount (mm) & 437 & 82 & - & 43 & 0 & 476 & 43 \\
\hline & Ratio & $84 \%$ & $16 \%$ & - & $8.4 \%$ & 0 & $92 \%$ & $8.4 \%$ \\
\hline \multirow{2}{*}{$\begin{array}{l}\text { Permeable } \\
\text { pavement }(15 \%)\end{array}$} & Amount (mm) & 437 & - & - & 383 & 16 & 38 & 399 \\
\hline & Ratio & - & - & - & $88 \%$ & $3.7 \%$ & $8.6 \%$ & $91 \%$ \\
\hline
\end{tabular}

Prec $^{\mathrm{a}}$ and Inflow ${ }^{\mathrm{b}}$ indicate the stormwater collected directly by the LID practices and the recharge from other

LID practices.

\subsection{LID performance in flood season}

The analysis above concerns the general peak runoffs in non-flood seasons. However, for two successive peak runoffs happening between $15^{\text {th }}$ Sep. 2018 and $24^{\text {th }}$ Sep. 2018 in flood season, all the five LID scenarios lost the peak reduction ability, as shown in Fig. 10. Table 8 records the specific total basin peak values. It is noticed that except for the peak happening on $23^{\text {rd }}$ Sep. 2018 in permeable pavements scenario, all the five LID scenarios

400 brought bigger peak values than CD scenario C. And further, the mixed LID scenario, which was supposed to be the most powerful runoff reduction plan, led to peak increases of $2 \%$ from $6.35 \mathrm{~mm}$ to $6.47 \mathrm{~mm}$ and from 3.57 $\mathrm{mm}$ to $3.65 \mathrm{~mm}$, which is $2.3 \%$. 
(a)

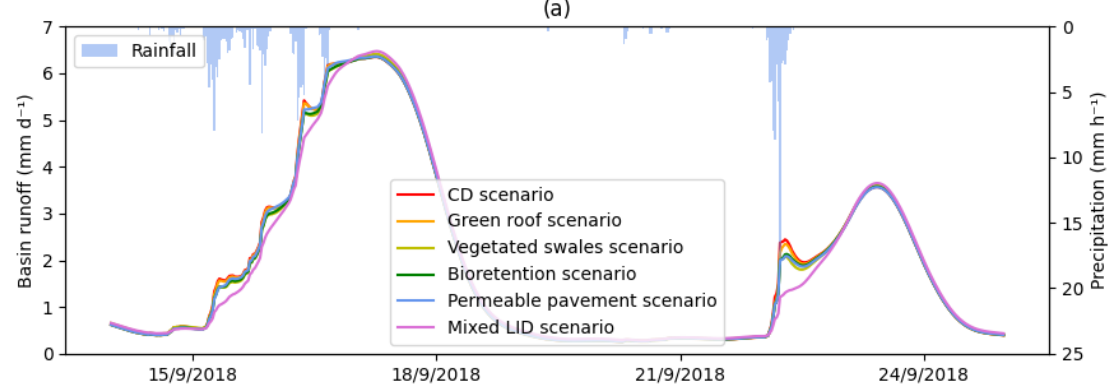

(b)

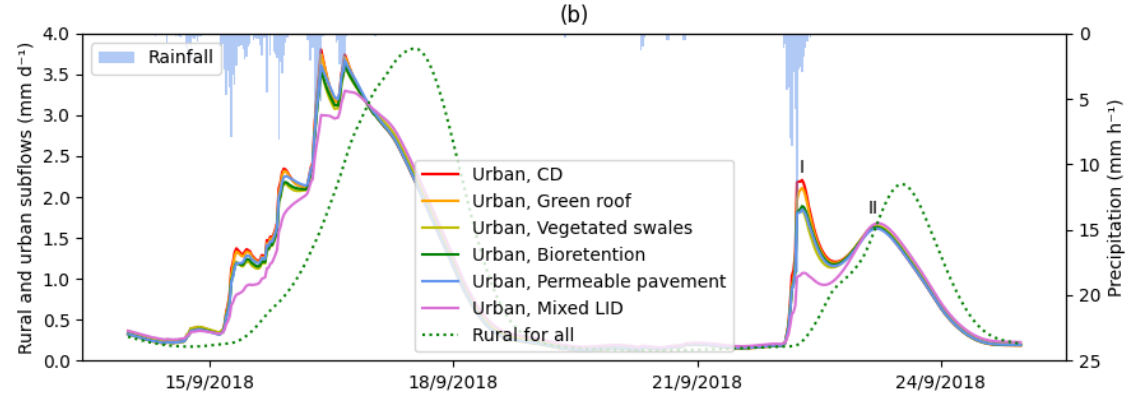

Figure 10: (a) Two successive total basin peaks in flood season and (b) their rural and urban sub-flows in five LID

scenarios and one $C D$ scenario $C$. The specific values of total basin peaks are shown in Table 11.

Table 11. The peak values of two total basin peak runoffs happening in flood season for five LID scenarios and one CD scenarios

\begin{tabular}{lllllll}
\hline Scenarios & $\begin{array}{l}\text { CD } \\
\text { scenario C }\end{array}$ & $\begin{array}{l}\text { Green } \\
\text { roof }\end{array}$ & $\begin{array}{l}\text { Vegetated } \\
\text { swales }\end{array}$ & $\begin{array}{l}\text { Biorete } \\
\text { ntion }\end{array}$ & $\begin{array}{l}\text { Permeable } \\
\text { pavement }\end{array}$ & $\begin{array}{l}\text { Mixed } \\
\text { LID }\end{array}$ \\
\hline Peak runoff in 19 ${ }^{\text {th }}$ Sep. $\left[\mathrm{mm} \mathrm{d}^{-1}\right]$ & 6.35 & 6.36 & 6.42 & 6.36 & 6.36 & 6.47 \\
Increase proportion $[-]$ & - & $0.1 \%$ & $1.0 \%$ & $0.1 \%$ & $0.1 \%$ & $2.0 \%$ \\
\hline Peak runoff in $23^{\text {rd }}$ Sep. $\left[\mathrm{mm} \mathrm{d}^{-1}\right]$ & 3.57 & 3.58 & 3.60 & 3.58 & $\mathbf{3 . 5 6}$ & 3.65 \\
Increase proportion $[-]$ & - & $0.4 \%$ & $1.0 \%$ & $0.3 \%$ & $\mathbf{- 0 . 1 \%}$ & $2.3 \%$ \\
\hline
\end{tabular}

This anomalous condition is triggered by the intensive rainfalls during flood season have exhausted the water retention capacity in rural areas, and therefore these peak runoffs are not only generated from urban areas but also from rural areas. The runoff delay function of LID practices slowed down part of urban peak runoff, which caused stacking of urban and rural peaks and in consequence increased the total basin peak runoff. As the second peak event on $23^{\text {rd }}$ Sep. 2018 shown in Fig. 10, the urban sub-flow occurred two summits generating from urban grey and green surfaces, respectively. The summit I of urban sub-flow in CD scenario C was almost erased by LID practices in mixed LID scenario, but the decreased summit I was partly delayed and

415 superimposed on the summit II, which brought a larger stack of urban and rural peaks and increased the total basin runoff by $2.3 \%$.

Even though the increase is small, it is to be concluded that during extremely wet conditions, the effect of implementing LID measures on peak flow reduction is negligible, if not negative in basins with combined urban and rural land use. 


\section{Discussions}

\subsection{Transferability of research results}

Since the specific geographical conditions of study catchment, the research results about the growing total basin peaks after LID implementations are limited to restricted regions and specific weather conditions. The transferability of the result presented here needs to consider the following characters in other catchments: First, the basin should have a substantial portion of urban area to make the effects relevant for downstream areas. Second, the location of urban areas ought to be close to the outlet of a (sub-)watershed to make the risk of stacking of faster urban peaks and slower rural peaks relevant, in particular in relation to LID implementation. Finally, the extent of LID implementation will quantitatively influence the basin peaks, as a higher degree of LID implementation may bring a larger stack of urban and rural sub-flow in flood seasons.

$430 \quad 5.2$ Limitations

To decrease the model uncertainty caused by over-complex models and to determine a suitable level of model complexity (Hrachowitz et al., 2014), this research used a relatively simple semi-distributed model to simulate the rainfall-runoff relationship on the catchment scale. Heterogeneity within the rural and urban areas is not represented in our semi-distributed model.

435 Then, important assumptions are used in the urban development and LID implementation scenarios. First, 2.4 million residents are supposed to live in San Antonio City with three compact factors $(0.85,0.9$, and 1$)$ for living space in 2040 in three urbanization scenarios. Uncertainty in these figures is high. Next, the extent of urban construction and LID implementation is assumed to be consistent throughout urban areas. However, the construction density of urban core areas might be larger than the new-developed suburban areas. Finally, five

440 LID implementation scenarios presume optimistic LID implementation conditions by using favorable LID parameters, hence overlooking practical implementation, operation, and maintenance problems such as the damage of LID practices and the blockage in soil media. All such limitations lead to discrepancy between the model results and reality. The results however show that the answer to our research question, "[what is] the influence of LID implementation on the basin peaks at a catchment scale" remains valid for different urban

445 development and LID implementation scenarios.

\subsection{Recommendations}

With regards to urbanization, the infill urban development strategy is recommended for flood control rather than the sprawl urban development strategy. Secondly, although urbanization may inevitably result in the rising of total runoff volume, extreme peak runoffs could be controlled by adjusting the ratio of urban grey and green areas and creating the time differences between the peak runoffs from these sub-areas. However, stacking of peak flows from urban and rural parts of the basin should be avoided by making use of the faster urban runoff versus the slower rural one.

To improve our understanding on total basin peak control, future research can study the hydrological response times of different landscapes. The sub-areas dominated by different land use categories, soil types, topographic conditions, urbanization extents, and their positions in one catchment can be studied. This research assumed homogeneous rural and urban hydrological patterns. Future research could further analyze this problem 
considering spatially heterogeneous areas, such as partial urban development and uneven LID implementation condition, using distributed models with more precise data supports.

\section{Conclusions}

In this research, a case study for the catchment of San Antonio, Texas was conducted to investigate the influence of LID implementation on the basin runoff at a catchment scale. Scenario analyses of both urban development and LID implementation were adopted to give a reliable answer to the research question. A SUPERFLEX conceptual model was adapted as a semi-distributed model to simulate the rainfall-runoff relationships of study catchment's hydrological behavior under different scenarios. It was found that:

1. The urban surface, taking $27 \%$ of study catchment, generated $63 \%$ of total basin runoff as $101 \mathrm{~mm}$ in 600 research days, while the last $73 \%$ rural areas only produced $37 \%$ of total runoff as $58 \mathrm{~mm}$. And with less water retention capacity urban areas yielded peak runoffs more frequently than rural areas.

2. The infill urban development strategy benefits more from runoff control than the sprawl urban development strategy. All three urban development scenarios brought growth of total runoff volume with increase ratios as high as $14.3 \%$ for scenario C (half-infill and half-expansion urban development plan), $8.7 \%$ for scenario B (70 $\%$-infill and $30 \%$-expansion), $2.7 \%$ for scenarios A (fully infill development). Fortunately, however, by converting the urban development strategy from urban expansion to infill development, the extreme peak runoff can be reduced from $8.6 \mathrm{~mm}$ (scenario C) to $8.0 \mathrm{~mm}$ (scenario B) and $7.1 \mathrm{~mm}$ (scenario A) that even smaller than $7.4 \mathrm{~mm}$ in the current situation.

475 3. All the five LID implementation scenarios performed powerful runoff reduction ability on the peak runoffs in non-flood seasons. Bioretention cells and permeable pavements can significantly decrease both total basin runoff volume (with the reduction ratios as $2.4 \%$ and $2.5 \%$ ) and peak values (8.8\% and $9.5 \%$ ). With more water input and less construction area (as the ratio of drainage to the construction area increases from 1 to 1.5), the water retention ability of bioretention cells, especially evaporation, can be better developed with almost the same proportion of overflow. Vegetated swales, without substantial water retention capacity, seem to perform a limited runoff volume reduction $(1 \%)$ than the other three LID practices but have satisfactory peak runoff reducing ability $(7.6 \%)$. On the contrary, green roofs have the worst peak runoff removal ability $(4.4 \%)$ and normal runoff volume reduction capability $(2.3 \%)$. The mixed LID scenario provides a forceful solution on runoff reduction as the typical peak runoff was decreased by $28.3 \%$, and the total basin runoff volume in 600 research days was restricted from $182 \mathrm{~mm}$ to $170 \mathrm{~mm}$ with a $6.9 \%$ reduction ratio.

4. However, when it comes to flood season, all the five LID scenarios lost the peak reduction ability, and a higher degree of LID implementation leads to larger total basin peak runoffs. This is because the runoff delay function of LID practices slowed urban peaks, which caused more stack of urban and rural sub-flows and thus increased the total basin runoff. Two consecutive peak runoffs happening in flood season rose by over $2 \%$ in

490 the mixed LID scenario.

Data availability: Precipitation, evaporation, and runoff data are available on the USGS website (https://www.usgs.gov/). The impervious surface data related to Fig. 1 were retrieved from NASA Socioeconomic Data and Applications Center (SEDAC, https://sedac.ciesin.columbia.edu/).

Code availability: Please contact the first author regarding code scripts. 
495 Author contribution: Conceptualization, F.V.; Data curation, X.S.; Formal analysis, X.S.; Funding acquisition, F.V.; Investigation, X.S.; Methodology, X.S.; Project administration, F.V.; Resources, X.S.; Software, X.S., Supervision, F.V.; Visualization, X.S.; Writing—original draft, X.S.; Writing—review \& editing, F.V. and X.S. All authors have read and agreed to the published version of the manuscript.

Competing interests: The authors declare that they have no conflict of interest.

\section{References}

Ahiablame, L. M., Engel, B. A., and Chaubey, I.: Effectiveness of Low Impact Development Practices: Literature Review and Suggestions for Future Research, Water, Air, \& Soil Pollution, 223(7), 4253-4273, doi:10.1007/s11270-012-1189-2, 2012

Ahiablame, L., and Shakya, R.: Modeling flood reduction effects of low impact development at a watershed

505 scale, Journal of Environmental Management, 171, 81-91, doi:10.1016/j.jenvman.2016.01.036, 2016

Bedan, E. S., and Clausen, J. C.: Stormwater runoff quality and quantity from traditional and low impact development watersheds 1, Jawra journal of the american water resources association, 45(4), 998-1008, doi:10.1111/j.1752-1688.2009.00342.x, 2009

Colstoun, B., C., E., Huang, C., Wang, P., Tilton, J. C., Tan, B., Phillips, J., Niemczura, S., Ling, P.-Y., and

Wolfe, R. E.: Global Man-made Impervious Surface (GMIS) Dataset From Landsat. Palisades, NY: NASA Socioeconomic Data and Applications Center (SEDAC). https://doi.org/10.7927/H4P55KKF, 2017

Carpenter, D. D., and Kaluvakolanu, P.: Effect of Roof Surface Type on Storm-Water Runoff from Full-Scale Roofs in a Temperate Climate, Journal of Irrigation and Drainage Engineering, 137(3), 161-169, doi:10.1061/(asce)ir.1943-4774.0000185, 2011

515 Carter, T., and Jackson, C. R.: Vegetated roofs for stormwater management at multiple spatial scales, Landscape and Urban Planning, 80(1-2), 84-94, doi:10.1016/j.landurbplan.2006.06.005, 2007

Carter, T. L., and Rasmussen, T. C.: Hydrologic Behavior Of Vegetated Roofs, Journal of the American Water Resources Association, 42(5), 1261-1274, doi:10.1111/j.1752-1688.2006.tb05611.x, 2016

Chapman, C., and Horner, R. R.: Performance Assessment of a Street-Drainage Bioretention System, Water

520 Environment Research, 82(2), 109-119, doi:10.2175/106143009x426112, 2010

Collins, K. A., Hunt, W. F., and Hathaway, J. M.: Hydrologic comparison of four types of permeable pavement and standard asphalt in eastern North Carolina, Journal of Hydrologic Engineering, 13(12), 1146-1157, doi: 10.1061/(asce)1084-0699(2008)13:12(1146), 2008

Debusk, K. M., and Wynn, T. M.: Storm-Water Bioretention for Runoff Quality and Quantity Mitigation,

Journal of Environmental Engineering, 137(9), 800-808, doi:10.1061/(asce)ee.1943-7870.0000388, 2011

Dietz, M. E.: Low Impact Development Practices: A Review of Current Research and Recommendations for Future Directions, Water, Air, and Soil Pollution, 186(1-4), 351-363, doi:10.1007/s11270-007-9484-z, 2007

Dreelin, E. A., Fowler, L., and Carroll, C. R.: A test of porous pavement effectiveness on clay soils during natural storm events, Water Research, 40(4), 799-805, doi:10.1016/j.watres.2005.12.002, 2006

530 Fenicia, F., Kavetski, D., and Savenije, H. H.: Elements of a flexible approach for conceptual hydrological modeling: 1. Motivation and theoretical development, Water Resources Research, 47(11), doi:10.1029/2010wr010174, 2011 
Gharari, S., Hrachowitz, M., Fenicia, F., Gao, H., and Savenije, H. H.: Using expert knowledge to increase realism in environmental system models can dramatically reduce the need for calibration, Hydrology and Earth System Sciences, 18(12), 4839-4859, doi:10.5194/hess-18-4839-2014, 2014

Gilroy, K. L., and Mccuen, R. H.: Spatio-temporal effects of low impact development practices, Journal of Hydrology, 367(3-4), 228-236, doi:10.1016/j.jhydrol.2009.01.008, 2009

Hostache, R., Chini, M., Giustarini, L., Neal, J., Kavetski, D., Wood, M., Corato, G., Pelich, R., and Matgen, P.: Near-Real-Time Assimilation of SAR-Derived Flood Maps for Improving Flood Forecasts, Water Resources

540 Research, doi:10.1029/2017wr022205, 2018

Hrachowitz, M., Savenije, H. H., Bogaard, T. A., Tetzlaff, D., and Soulsby, C.: What can flux tracking teach us about water age distribution patterns and their temporal dynamics? Hydrology and Earth System Sciences, 17(2), 533-564, doi:10.5194/hess-17-533-2013, 2013

Hrachowitz, M., Fovet, O., Ruiz, L., Euser, T., Gharari, S., Nijzink, R., Freer, J., Savenije, H. H., and Gascuel-

Odoux, C.: Process consistency in models: The importance of system signatures, expert knowledge, and process complexity, Water Resources Research, 50(9), 7445-7469, doi:10.1002/2014wr015484, 2014

Hunt, B., Stevens, S., and Mayes, D.: Permeable Pavement Use and Research at Two Sites in Eastern North Carolina, Global Solutions for Urban Drainage, doi:10.1061/40644(2002)39, 2002

Hunt, W. F., Smith, J. T., Jadlocki, S. J., Hathaway, J. M., and Eubanks, P. R.: Pollutant Removal and Peak

550 Flow Mitigation by a Bioretention Cell in Urban Charlotte, N.C, Journal of Environmental Engineering, 134(5), 403-408, doi:10.1061/(asce)0733-9372(2008)134:5(403), 2008

Hunt, W. F., Hathaway, J. M., Winston, R. J., and Jadlocki, S. J.: Runoff Volume Reduction by a Level Spreader-Vegetated Filter Strip System in Suburban Charlotte, N.C, Journal of Hydrologic Engineering, 15(6), 499-503, doi:10.1061/(asce)he.1943-5584.0000160, 2010

555 Kavetski, D., and Fenicia, F.: Elements of a flexible approach for conceptual hydrological modeling: 2. Application and experimental insights, Water Resources Research, 47(11), doi:10.1029/2011wr010748, 2011

Li, H., Sharkey, L. J., Hunt, W. F., and Davis, A. P.: Mitigation of Impervious Surface Hydrology Using Bioretention in North Carolina and Maryland, Journal of Hydrologic Engineering, 14(4), 407-415, doi:10.1061/(asce)1084-0699(2009)14:4(407), 2009

560 Ready, S. C., and Montoya, A.: SA Climate Ready: A Pathway for Climate Action \& Adaptation., Sociology \& Anthropology Faculty Research, 52, https://digitalcommons.trinity.edu/socanthro_faculty/52, 2019

Qin, H. P., Li, Z. X., and Fu, G.: The effects of low impact development on urban flooding under different rainfall characteristics, Journal of environmental management, 129, 577-585, doi: 10.1016/j.jenvman.2013.08.026, 2013

565 Rushton, B. T.: Low-Impact Parking Lot Design Reduces Runoff and Pollutant Loads, Journal of Water Resources Planning and Management, 127(3), 172-179, doi:10.1061/(asce)0733-9496(2001)127:3(172), 2001 San Antonio River Authority; Bexar Regional Watershed Management's Low Impact Development Manual Technical Subcommittee, San Antonio River Basin Low Impact Development Technical Design Guidance Manual, San Antonio, TX, USA., 2015

570 San Antonio Water System, Water Recycling: https://www.saws.org/your-water/water-recycling/, last access: 08 September, 2020. 
Savenije, H. H.: HESS Opinions "Topography driven conceptual modelling (FLEX-Topo)", Hydrology and Earth System Sciences Discussions, 7(4), 4635-4656, doi:10.5194/hessd-7-4635-2010, 2010

Soulis, K. X., Valiantzas, J. D., Ntoulas, N., Kargas, G., and Nektarios, P. A.: Simulation of green roof runoff under different substrate depths and vegetation covers by coupling a simple conceptual and a physically based hydrological model, Journal of Environmental Management, 200, 434-445, doi:10.1016/j.jenvman.2017.06.012, 2017

The City of San Antonio - Official City Website: https://www.sanantonio.gov/, last access: 08 September, 2020. The Edwards Aquifer Website: http://edwardsaquifer.net/, last access: 08 September, 2020.

580 Ulkü, M., Sui, X., van der Lans, M., Dillon Peynado, T., Zheng, J., and Fong, C.: Sponge City Project, Multidisciplinary project report, Delft University of Technology, http://resolver.tudelft.nl/uuid:58200b07-ee0142e8-8a0f-8881dcda5c07, 2018

Van Seters, T., Smith, D., and MacMillan, G.: Performance evaluation of permeable pavement and a bioretention swale, in: Proceedings eighth international conference on concrete block paving, San Francisco, 585 California USA, 6-8 November, 2006

Vanwoert, N. D., Rowe, D. B., Andresen, J. A., Rugh, C. L., Fernandez, R. T., and Xiao, L.: Green Roof Stormwater Retention, Journal of Environmental Quality, 34(3), 1036-1044, doi:10.2134/jeq2004.0364, 2005 